\title{
High-resolution monitoring of VFA dynamics reveals process failure and exponential decrease of biogas production
}

\author{
Kerstin Maurus $^{1}$ D $\cdot$ Nicola Kremmeter $^{1} \cdot$ Sharif Ahmed $^{1} \cdot$ Marian Kazda $^{1}$
}

Received: 17 June 2021 / Revised: 6 October 2021 / Accepted: 19 October 2021

(c) The Author(s) 2021, corrected publication 2022

\begin{abstract}
The future of biogas production will be characterized by on-demand provision to compensate the unpredictability of solar and wind power. Such biogas production through feedstock management is a promising possibility but requires close monitoring. The dynamics of volatile fatty acid (VFA) formation and further degradation to methane production are of special interest when providing high portions of fast degradable carbohydrates. Their fast degradability can impair process stability. The correlation of VFA loading and the biogas process was tested in four anaerobic continuously stirred tank reactors supplied with maize silage hourly and with sugar beet silage twice a day at a 12-h interval. The reactors differed in the amount of sugar beet silage and thus in total organic loading rate from 2.0 to $3.5 \mathrm{~kg}_{\mathrm{vs}} \mathrm{m}^{-3}$ day ${ }^{-1}$. The VFA concentrations increased immediately after each input of sugar beet silage but levelled down until the next feeding period. At the highest organic loading rate, successive VFA accumulation escalated after 25 days (50 feeding periods) at $3.5 \mathrm{~kg}_{\mathrm{vs}} \mathrm{m}^{-3} \mathrm{day}^{-1}$, causing process failure with propionic acid concentrations exceeding $3500 \mathrm{mg} \mathrm{L}^{-1}$. The data revealed a strong negative exponential relationship between VFA concentrations and biogas and methane yields, respectively. High-resolution monitoring showed the instant dynamics of VFA production after intermittent sugar beet silage supply and the cumulative impact during increasing process disturbance.
\end{abstract}

Keywords Anaerobic digestion $\cdot$ Biogas $\cdot$ Volatile fatty acids $\cdot$ Sugar beet silage $\cdot$ Intermittent feeding

\section{Introduction}

In addition to wind power and photovoltaics, biogas is an important renewable energy source, especially as electricity and heat can be produced independently of the weather, daytime, and season. On-demand (flexible) biogas plants can compensate for the lack of predictability of wind and solar power and thus balance the power grid. In addition to

Kerstin Maurus and Nicola Kremmeter contributed equally to this manuscript.

Kerstin Maurus

kerstin.maurus@uni-ulm.de

Nicola Kremmeter

nkremmeter@gmx.de

Sharif Ahmed

sharif.ahmed@uni-ulm.de

Marian Kazda

marian.kazda@uni-ulm.de

1 Institute of Systematic Botany and Ecology, Ulm University, Albert-Einstein-Allee 11, 89081 Ulm, Germany technical flexibilisation attempts (storing biogas and controlling its combustion), also biological flexibilisation can be implemented through feedstock management [1, 2]. According to the demand of the energy market, biogas production is increased and decreased with intermittent feedstock supply. Supported with prediction models validating weather development as well as electricity production from other renewable sources against energy consumption, biogas can be used for electricity generation. This operation mode is generally performed with feedstocks with a high share of fast degradable carbohydrates like sugar beet silage [3]. They are easily degraded to volatile fatty acids (VFA) to form the final product methane later $[4,5]$. In contrast to fiber-rich carbohydrates, hydrolysis proceeds immediately if it has not already started during the ensiling process [6, 7]. Mixing fast degradable carbohydrates with fibrous feedstocks can furthermore improve their decomposition promoting microbial activity of all degradation stages, eventually also changing the share of intermediates $[8,9]$.

Various studies have already tested the applicability of intermittent feedstock supply to produce readily available methane within a short amount of time. Different approaches 
to flexible biogas production have been tested concerning the frequency of feeding events, the organic loading rate, and different feedstock mixtures [4, 10-12]. It was also shown that significantly higher biogas and methane yields can be achieved with intermittent supply versus continuous (hourly) supply [12-14]. Nevertheless, ample amounts of feedstock, especially fast degradable carbohydrates, can be a stress factor for anaerobic digestion (AD) causing process failure in the worst case [3, 5].

Most studies regarding flexible biogas production focus on the final biogas and methane yield and the influence of feedstock management on these parameters. However, to fully implement flexible operation mode and to prevent process failure, it is important to monitor and to understand the feedstock degradation kinetics and the impact of $\mathrm{AD}$ intermediates. Laperrière et al. [15] have shown that intermittently provided organic materials can delay biogas production due to acidification and thus decreasing the methane yield for the first hours after the feeding event.

At intermittent feeding mode, VFA, which are formed during the first degradation steps, have to be immediately degraded further for a stable fermentation process [16]. If VFA degradation is impaired, the acids accumulate in the fermenter slurry [17], which often occurs when degradation kinetics are higher in the first AD steps compared to the methanogenesis. The accumulation of VFA leads to a decrease in $\mathrm{pH}$, which in turn again affects the $\mathrm{AD}$ [18]. Mathai et al. [19] were able to show a shift and decrease in microbial communities related to VFA degradation during overload conditions. When operating biogas plants for on-demand production, punctual overloads are part of the feedstock management. Escalating VFA accumulations can thus be a possible disturbance for the biogas process.

Timely close monitoring of VFA is important to identify stress situations for microorganisms and to prevent the reactor from collapsing [20]. The correlation of VFA concentration and process stability still needs to be investigated more in detail, especially when fast degradable carbohydrates are used for flexible biogas production.

The underlying hypotheses in this laboratory study were (1) that increasing intermittent feedstock supply results in specifiable AD process impacts in biogas plants. Further, that (2) high-resolution tracking of VFA reflects the dynamics and stability of the degradation process when easily degradable carbohydrates are supplied, and as a result (3) that there is a direct relationship between VFA burden and biogas and methane yields, respectively.

Most biogas plants are still operated under continuous conditions to avoid process instabilities or failure. The transition to flexible feeding systems is hampered by the lack of insights into the complex biological and physio-chemical procedures and reactions [15]. This study, therefore, tested the given hypotheses in four continuously stirred tank reactors (CSTR) with common agricultural feedstocks at increasing organic loading rates of fast degradable carbohydrates (sugar beet silage). The experiments aim to firstly specify the relationship between process overload and methane gain to improve understanding of the AD process under intermittent feeding conditions.

\section{Materials and methods}

\subsection{Experimental setup}

The experiment was performed in four CSTR, which had a capacity of $20.3 \mathrm{~L}$ each (Fig. 1). Thereof $16.5 \mathrm{~L}$ were filled with slurry (operating volume) and $3.8 \mathrm{~L}$ were used as gas-filled compartment. Overflows with a capacity of $4 \mathrm{~L}$ each ensured that the liquid content did not exceed the 16.5 L mark. Using electrical heating panels attached to the outer reactor walls, the slurry was constantly heated to a mesophilic temperature of $40{ }^{\circ} \mathrm{C}$. The gas-tight CSTRs were stirred (every $20 \mathrm{~min}$ for $10 \mathrm{~min}$ at $75 \mathrm{rpm}$ ) by paddle mixers, which ensured a homogeneous mixing enabling the microorganisms to reach and implement the provided feedstocks [21].

Maize silage (M) and sugar beet silage (S) were used as feedstocks in the present study. An automatic feeding system on a platform with 72 vessels was used to introduce $\mathrm{M}$ into the reactor. The content of each vessel was transported into the biogas reactor by an electric stamp. S was pumped into the reactors through flexible tubes by peristaltic pumps (MDX TI/10, MDX Biotechnik International GmbH, Noerten-Hardenberg, Germany) with additional timer switches. The CSTRs were supplied with M every hour. The daily amount of $\mathrm{S}$ was split into two portions given intermittently twice a day (every $12 \mathrm{~h}$ ).

In the beginning, the inoculum was sieved and degassed to avoid residual gas in the experimental data. The reactors were filled with $15 \mathrm{~L}$ inoculum and $1.5 \mathrm{~L}$ water to start the fermentation. Subsequently, the OLR was gradually increased with $\mathrm{M}$ and $\mathrm{S}$ every two to three weeks, according to Schnürer et al. [22] (Table 1).

The present high-resolution data evaluation reported here (part 3) started after 238 days of previous experiments and lasted for 32 days, until process disturbance occurred under specific circumstances. The reactors differed in the amount of $S$ that was given intermittently with OLR $0.5 \mathrm{~kg}_{\mathrm{VS}} \mathrm{m}^{-3}$ day $^{-1}$ in CSTR $1,1.0 \mathrm{~kg}_{\mathrm{VS}} \mathrm{m}^{-3}$ day $^{-1}$ in CSTR2, $1.5 \mathrm{~kg}_{\mathrm{VS}} \mathrm{m}^{-3} \mathrm{day}^{-1}$ in CSTR3, and 2.0 $\mathrm{kg}_{\mathrm{VS}} \mathrm{m}^{-3}$ day $^{-1}$ in CSTR4, respectively, and thus also in total OLR. All reactors were additionally supplied hourly with maize silage at constant OLR $1.5 \mathrm{~kg}_{\mathrm{vs}} \mathrm{m}^{-3}$ day $^{-1}$ (Table 1). Previous stages of this experiment were performed at the same OLR for maize silage for all reactors (1.5 
Fig. 1 Schematic diagram of laboratory reactors. $\mathrm{M}$ maize silage; ES electric stamp; MO motor; MC milligascounter; MS methane sensor; DL datalogger; ST sampling tube; $\mathrm{T}$ temperature sensor; $\mathrm{pH} \mathrm{pH}$ sensor; $\mathrm{S}$ sugar beet silage; HP heating panel

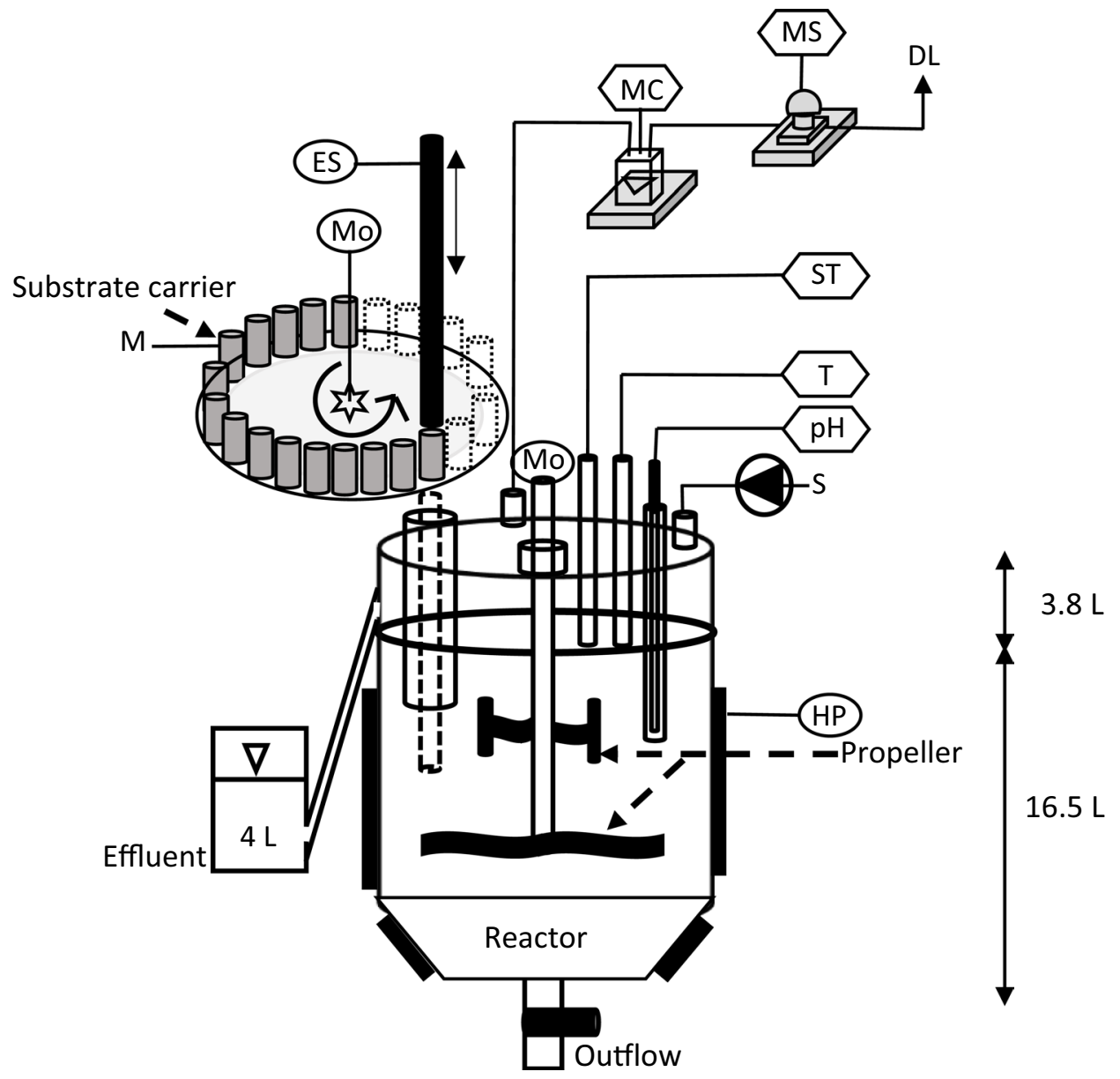

Table 1 Experimental conditions for the operated CSTR during highresolution VFA data evaluation (data given for part 3 of the experiment, for previous operation data see materials and methods)

\begin{tabular}{llllll}
\hline & Unit & CSTR1 & CSTR2 & CSTR3 & CSTR4 \\
\hline $\mathrm{M}$ & $\mathrm{g} \mathrm{day}^{-1}$ & 68.5 & & & \\
$\mathrm{~S}$ & $\mathrm{~g} \mathrm{day}^{-1}$ & 47.0 & 94.0 & 140.9 & 187.9 \\
OLR (total) & $\mathrm{kg}_{\mathrm{VS}} \mathrm{m}^{-3} \mathrm{day}^{-1}$ & 2.0 & 2.5 & 3.0 & 3.5 \\
OLR (M) & $\mathrm{kg}_{\mathrm{VS}} \mathrm{m}^{-3} \mathrm{day}^{-1}$ & 1.5 & & & \\
OLR (S) & $\mathrm{kg}_{\mathrm{VS}} \mathrm{m}^{-3} \mathrm{day}^{-1}$ & 0.5 & 1.0 & 1.5 & 2.0 \\
$\mathrm{M}: \mathrm{S}$ & - & $3: 1$ & $3: 2$ & $1: 1$ & $3: 4$ \\
\hline
\end{tabular}

CSTR continuously stirred tank reactor, $M$ maize silage, $S$ sugar beet silage, $O L R$ organic loading rate

$\mathrm{kg}_{\mathrm{vS}} \mathrm{m}^{-3} \mathrm{day}^{-1}$ ) but started with lower OLR for $\mathrm{S}$, which was gradually increased. Part 1 of the experiment with intermittent $\mathrm{S}$ supply was performed at OLR $0.5 \mathrm{~kg}_{\mathrm{vS}} \mathrm{m}^{-3} \mathrm{day}^{-1}$ (CSTR1), $0.7 \mathrm{~kg}_{\mathrm{vs}} \mathrm{m}^{-3} \mathrm{day}^{-1}$ (CSTR2), $0.9 \mathrm{~kg}_{\mathrm{vS}} \mathrm{m}^{-3}$ day $^{-1}$ (CSTR3), and $1.1 \mathrm{~kg}_{\mathrm{VS}} \mathrm{m}^{-3} \mathrm{day}^{-1}$ (CSTR4) for 62 days. Part 2 was performed with intermittent S supply at OLR 0.5 $\mathrm{kg}_{\mathrm{VS}} \mathrm{m}^{-3}$ day $^{-1}$ (CSTR1), $1.0 \mathrm{~kg}_{\mathrm{VS}} \mathrm{m}^{-3}$ day $^{-1}$ (CSTR2), 1.2 $\mathrm{kg}_{\mathrm{vS}} \mathrm{m}^{-3}$ day $^{-1}$ (CSTR3), and $1.5 \mathrm{~kg}_{\mathrm{vs}} \mathrm{m}^{-3}$ day $^{-1}$ (CSTR4) for 35 days.
TS and VS measurement was performed according to standard methods $2540 \mathrm{~B}$ and $2540 \mathrm{E}$. With drying and burning the samples at different temperatures, volatile components cannot be detected when determining the VS, however. For the exact determination of the OLR and specific yields, the measured VS has to be mathematically corrected [23], thus leading to presumable higher total OLR. Since the direct comparison of the reactors and the acid load were in focus of this study, the correction was not calculated.

\subsection{Inoculum and feedstock characterization}

Maize and sugar beet silage were provided by agricultural farms in the south of Germany. Both silages were stored at $-20{ }^{\circ} \mathrm{C}$. Shortly before usage, they were defrosted and stored at $5{ }^{\circ} \mathrm{C}$. S was pureed and diluted with water $1: 1$, to avoid clogging of the flexible supply tubes of the peristaltic pumps. The data in Table 1 refers to the pure, undiluted amount of S. M was cut with scissors into one centimetre long pieces before adding to the vessels on the platform. The inoculum was taken from a mesophilic agricultural plant. Feedstock characteristics $\mathrm{pH}$ value, carbon and nitrogen content, and total and volatile solids were determined before the 
experiment. Compositional analysis was performed by the institute LUFA Nord-West (Oldenburg, Germany) (Table 2).

\subsection{Analytical methods}

The resulting biogas of each CSTR was guided through milligascounters (MGC-10, Ritter GmbH, Bochum, Germany) and infrared sensors measuring the methane content (BCP$\mathrm{CH} 4$, BlueSens gas sensor GmbH, Herten, Germany) via gas-tight tubes. Biogas volume and methane content were recorded every $10 \mathrm{~min}$. The data was transmitted to a computer via a data logger and recorded with BacVis 7.6.0.2 software (Bluesense GmbH, Herten, Germany).

The $\mathrm{pH}$ and VFA/TIC (volatile fatty acid to total inorganic carbon ratio) values of the fermentation slurries were determined by manual measurements once or twice a week. All reactors had a sampling dip tube (Fig. 1), which was used to take samples. The VFA/TIC values were measured according to DIN 38 409-H7 [24] using the titration apparatus Dosimet 665 (Metrohm, Hersau, Switzerland).

Samples for acid monitoring were taken on six experimental days at five points, respectively. The first sampling for each day was taken before the addition of $\mathrm{S}$ and the second sampling was done five minutes after loading was completed. After 1, 2, and $4 \mathrm{~h}$, further samples were taken from each CSTR. The samples were tested on their content of acetic acid, propionic acid, and butyric acid. For gas chromatography (GC) analysis $5 \mathrm{ml}$ of the samples were given in a $5 \mathrm{ml}$ Eppendorf tube (Eppendorf AG, Hamburg) and were frozen until further processing. After the samples were thawed, they were centrifuged for $20 \mathrm{~min}$ at $15^{\circ} \mathrm{C}$ and

Table 2 Feedstock and inoculum characterization

\begin{tabular}{llrrl}
\hline & Unit & M & \multicolumn{1}{l}{$\mathrm{S}$} & Inoculum \\
\hline $\mathrm{pH}$ & - & 3.5 & 3.6 & 8.9 \\
Total solids & $\%^{\mathrm{a}}$ & 37.5 & 20.1 & 3.5 \\
Volatile solids & $\%^{\mathrm{b}}$ & 96.4 & 87.2 & 65.8 \\
Carbon (C) & $\%^{\mathrm{b}}$ & 46.0 & 42.1 & 37.9 \\
Nitrogen (N) & $\%^{\mathrm{b}}$ & 1.2 & 0.7 & 3.4 \\
C/N ratio & - & 38.3 & 60.1 & 11.1 \\
Raw protein $(\mathrm{N} \times 6,25)$ & $\mathrm{g} / 100 \mathrm{~g}^{\mathrm{b}}$ & 5.8 & 3.8 & $\mathrm{ND}$ \\
Raw fat & $\mathrm{g} / 100 \mathrm{~g}^{\mathrm{b}}$ & 3.0 & 0.2 & $\mathrm{ND}$ \\
Starch & $\mathrm{g} / 100 \mathrm{~g}^{\mathrm{b}}$ & 33.0 & 13.4 & $\mathrm{ND}$ \\
Total sugars & $\mathrm{g} / 100 \mathrm{~g}^{\mathrm{b}}$ & $<0.5$ & 20.8 & $\mathrm{ND}$ \\
Raw fiber & $\mathrm{g} / 100 \mathrm{~g}^{\mathrm{b}}$ & 19.3 & 4.8 & $\mathrm{ND}$ \\
Acid detergent fiber & $\mathrm{g} / 100 \mathrm{~g}^{\mathrm{b}}$ & 22.8 & 5.5 & $\mathrm{ND}$ \\
Lignin & $\mathrm{g} / 100 \mathrm{~g}^{\mathrm{b}}$ & 1.9 & 1.3 & $\mathrm{ND}$ \\
Neutral detergent fiber & $\mathrm{g} / 100 \mathrm{~g}^{\mathrm{b}}$ & 35.8 & 8.9 & $\mathrm{ND}$ \\
\hline
\end{tabular}

$M$ maize silage, $S$ sugar beet silage

${ }^{\text {a}}$ Fresh mass of sample

${ }^{\mathrm{b}}$ Total solid mass of sample
14,000 rpm (Centrifuge 5427 R, Eppendorf AG, Hamburg). Subsequently, $1 \mathrm{ml}$ of supernatant was transferred to a $1.5 \mathrm{ml}$ Eppendorf tube and mixed with $100 \mu \mathrm{l}$ acid solution (2 M $\mathrm{HCl}+62.5 \mathrm{mg}$ butanol as internal standard). After foaming was completed, the samples were centrifuged again for $20 \mathrm{~min}$ at $15{ }^{\circ} \mathrm{C}$ with $12,700 \mathrm{rpm}$. The supernatant of each sample was then transferred to a GC sample vessel and stored at $7{ }^{\circ} \mathrm{C}$ for a maximum of 2 days until it was analysed in the gas chromatograph (Clarus 580, PerkinElmer Life and Analytical Sciences, Shelton, CT 06,484, USA). For analysis in the gas chromatograph, the sample was taken from an injector and injected into the column together with the carrier gas helium (Elite-FAMEWAX, $30 \mathrm{~m}, 0.25 \mathrm{~mm}$ ID, 0.25 microns df, PerkinElmer Life and Analytical Sciences, Shelton, CT 06,484, USA). The temperature of the column was increased from $110{ }^{\circ} \mathrm{C}$ to $180{ }^{\circ} \mathrm{C}$ during the flow. A flame ionization detector was used to detect the sample components.

\subsection{Data evaluation and statistics}

Specific biogas yield (sBY) and specific methane yield (sMY) were calculated based on OLR of the respective CSTR. Therefore, each day was split into periods (n) of $12 \mathrm{~h}$, each starting with the intermittent input of S. Each period contained 72 readings and led to a high number of observations. Periods with technical problems like delayed addition of $\mathrm{S}$ were excluded from the sBY and sMY calculation.

Microsoft Excel 2010 (Microsoft Corp., Redmond, USA), Origin Pro 2019B (OriginLab, Northampton, USA), and IBM SPSS Statistics 21 (IBM Corp., Armonk, USA) were used for further data analysis. Normal distribution was calculated with Shapiro-Wilk test, and Levene's test was applied to check the equality of variances. As data was not normally distributed and variances were not homogeneous, Welch's ANOVA and additional post hoc Games-Howell test were used to find significant differences between the CSTR. The significance level was adjusted at $p<0.05$.

\section{Results and discussion}

\subsection{Process stability monitoring}

According to Drosg [25], biogas processes are stable when the fermentation slurry $\mathrm{pH}$ ranges from 7.0 to 8.0. If the $\mathrm{pH}$ decreases further, growth of methanogens can be inhibited and digester failure is possible [26, 27]. The $\mathrm{pH}$ values for CSTR1-CSTR3 varied from 7.5 to 8.1 and fluctuated only about 0.5 units, respectively (Fig. 2a). In CSTR4, the $\mathrm{pH}$ decreased from day 253 onwards clearly indicated a process disturbance. Within 5 days, the $\mathrm{pH}$ value dropped 


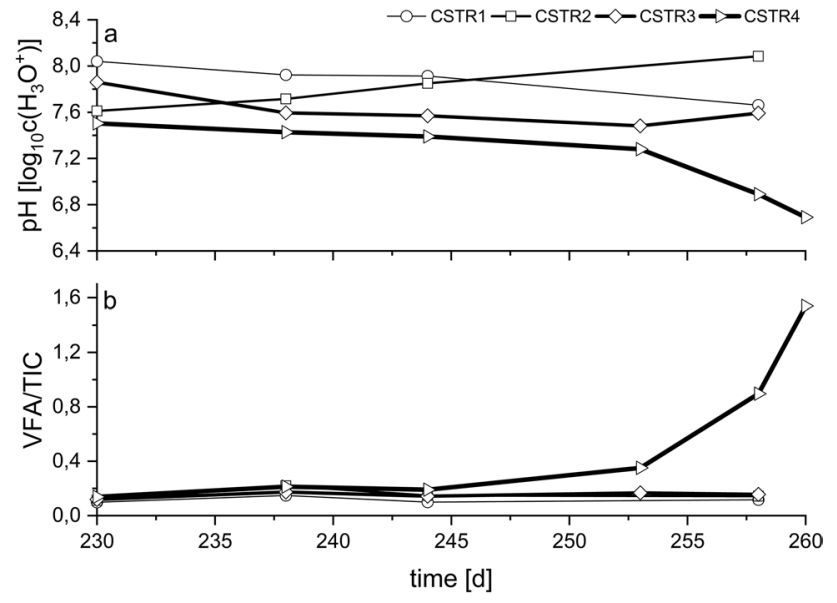

Fig. $2 \mathrm{pH}$ (a) and VFA/TIC (b) of the four CSTR during the measuring time of 32 days. The line thickness for each reactor is ordered according to increasing OLR and S proportion. CSTR continuously stirred tank reactor, VFA/TIC volatile fatty acid to total inorganic carbon ratio

from 7.3 (day 253) to 6.9 (day 258) and further to 6.7 on the last day of measurements (day 260).

The $\mathrm{pH}$ drop in this experiment was not only caused by VFA accumulation during AD but also by the input of acidic silages (pH 3.6 for sugar beet silage). S often already contains a high amount of organic acids and alcohols, which arise through hydrolysis that already starts during storage [28].

To get a more profound insight into reactor performance, the VFA/TIC is widely used in the biogas industry [24]. The ratio of VFAs to buffer capacity quickly displays changes in the fermentation slurry and is, therefore, better suited for monitoring than the $\mathrm{pH}$ value (Fig. 2b). According to Voß et al. [24], biogas processes with VFA/TIC values from 0.15 to 0.45 are considered stable for agricultural plants. The reactors CSTR1-CSTR3 were slightly below or in this range with values from 0.10 to 0.17 throughout this study. Reactor CSTR1 with an OLR of $2.0 \mathrm{~kg}_{\mathrm{VS}} \mathrm{m}^{-3}$ day $^{-1}$ had the lowest VFA/TIC ratio between 0.09 and 0.11 . Thus, CSTR 1 could digest more feedstock at a stable process. In contrast, the VFA/TIC in CSTR4 increased continuously throughout the experiment from 0.14 (day 230) up to 1.54 (day 260). Within the last 7 days, the VFA/TIC value increased rapidly by more than 1 . This fast increase and the simultaneous $\mathrm{pH}$ drop indicated that the load of $2.5 \mathrm{~kg}_{\mathrm{VS}} \mathrm{m}^{-3} \mathrm{day}^{-1}$ of intermittently provided sugar beet silage (total OLR $3.5 \mathrm{~kg}_{\mathrm{VS}} \mathrm{m}^{-3} \mathrm{~d}^{-1}$ ) led to VFA accumulation and exceeded the capacity of the last AD steps. Wilches et al. [20] observed the response of VFA/TIC on flexible feedstock management in a full-scale biogas plant. They observed process instabilities and a decrease of methane yield already from VFA/TIC values of $0.4 \mathrm{on}$.
Reactor CSTR4 in which process failure occurred was provided with a feedstock ratio of 3:4 (maize silage: sugar beet silage, based on VS). The high-resolution monitoring of VFA revealed that the acids were severely accumulated within a short amount of time ( 25 days) of intermittent feeding by sugar beet silage at the latest OLR. Demirel et al. [29] have shown that even monodigestion of sugar beet silage (continuous feeding) can be performed for over 150 days with OLR reaching up to $7.4 \mathrm{~kg}_{\mathrm{vs}} \mathrm{m}^{-3}$ day $^{-1}$, but postulated possible lack of micronutrients in such mono-digestion experiments. Since all four reactors were continuously fed with the identical amount of maize silage but stepwise increasing sugar beet silage ratios, it is unlikely that trace element shortage would cause such a rapid process failure as occurred within few days in the CSTR4.

\subsection{High-resolution volatile fatty acid pattern}

Former studies have already shown the instant degradation of $S$ when given intermittently into biogas reactors [5-7] and thus providing rapidly available VFAs, alcohols, and sugars [30]. Throughout the fermentation the OLR was gradually increased in three steps (phase 1-3) while constant VFA monitoring (Fig. 3). The acetate concentration in CSTR4 increased at the beginning of OLR phase 2 but went back to normal after 20 days (Fig. 3a).

CSTRs 1 to 3 did not show a loss of stability, when the OLR was increased again in phase 3. However, 21 days after the start of the phase 3 , the concentration of propionic acid in CSTR4 rocketed to over $3000 \mathrm{mg} \mathrm{L}^{-1}$ within only 1 week (Fig. 3b). Klang et al. [31] tested the effects of changing environments (e.g., exchanging sugar beet silage for maize silage and vice versa) on the biogas microbiomes. While the archaeal communities did not change during their 8-week test phase after the feedstock change, the bacterial communities adapted. They assumed that the accumulation of propionic acid in the reactor switched from maize to sugar beet silage indicated a shift from the acetoclastic to the hydrogenotrophic pathway.

The immediate effects of intermittent $\mathrm{S}$ loading were investigated by high timely resolution of VFA patterns. For a better overview the days 244, 253, and 260 are shown graphically (Fig. 4). In all CSTRs, the acid concentration increased after the addition of S. While acetate peaked in the first measurement after the S supply, the increase of propionate lasted longer. Except for the high-OLR reactor CSTR4, the VFA concentrations tapered off to initial values until the next $\mathrm{S}$ supply.

The acetate concentration did slightly increase in all reactors throughout the experiment but always showing a decline after every feeding event and acid degradation within the observation period of four hours except for CSTR3, day 260. No other process parameter for CSTR 3 indicated a process 
Fig. 3 Acetate (a) and propionate (b) concentration during the experimental time after reaching OLR $2,0 \mathrm{~kg}_{\mathrm{vs}} \mathrm{m}^{-3} \mathrm{day}^{-1}$.

Dashed lines show the increase of OLR with the different phases. CSTR continuously stirred tank reactor

Fig. 4 Acetate $(\mathbf{a}, \mathbf{c}, \mathbf{e})$ and propionate $(\mathbf{b}, \mathbf{d}, \mathbf{f})$ concentrations during the addition of sugar beet silage (S). Data are shown for samples taken on experimental days 244 (a, b), 253 (c, d), and 260 (e, f). S was added right after the first sampling for VFA measurement. Line thickness for each reactor is ordered according to increasing OLR and $\mathrm{S}$ proportion. Note different scales of the $Y$-axis for propionate in sub-figures $\mathbf{d}$ and $\mathbf{f}$. CSTR continuously stirred tank reactor, VFA volatile fatty acids

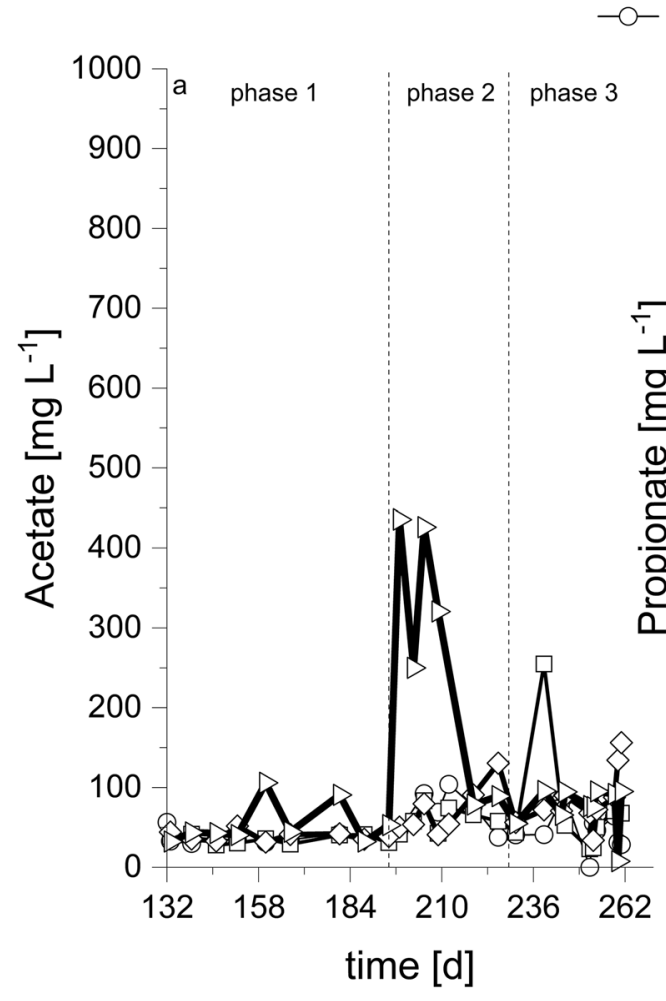

$-\operatorname{CSTR} 1 \multimap \square-\operatorname{CSTR} 2 \sim \operatorname{CSTR} 3 \leadsto$ CSTR 4

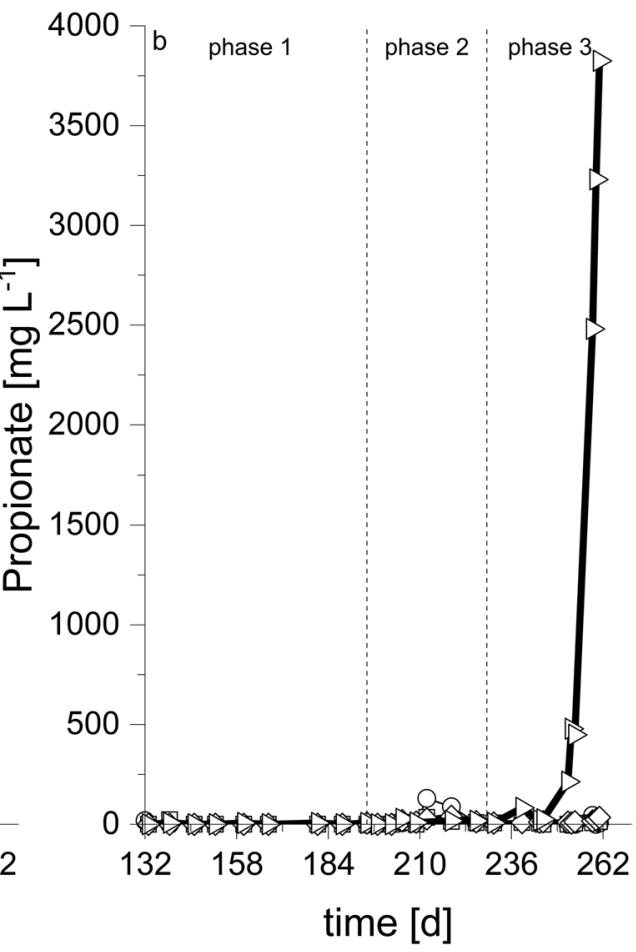

$\multimap$ CSTR $1 \multimap$ CSTR $2 \prec$ CSTR $3 \longrightarrow$ CSTR 4

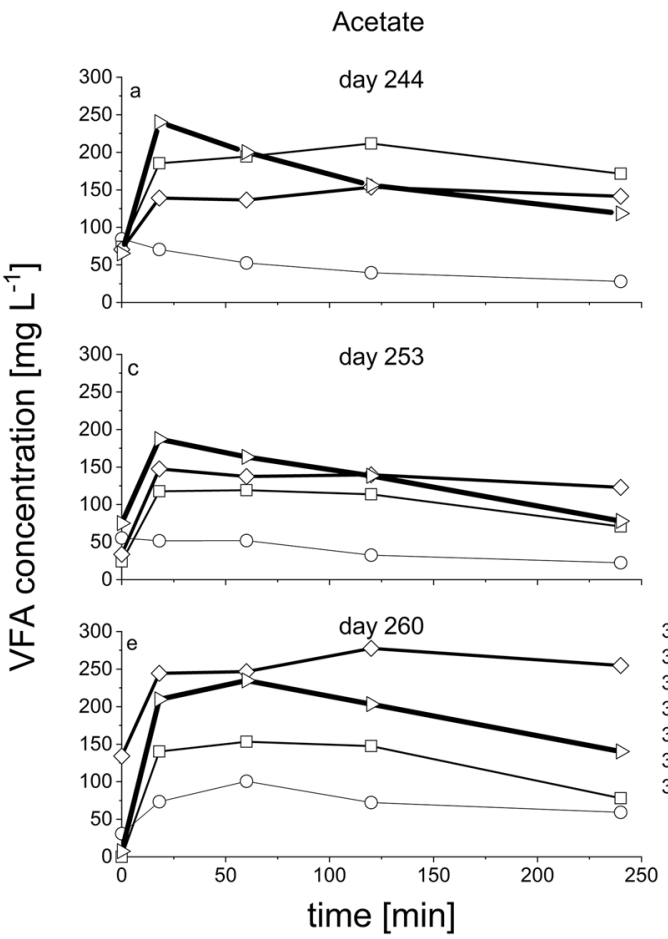

Propionate
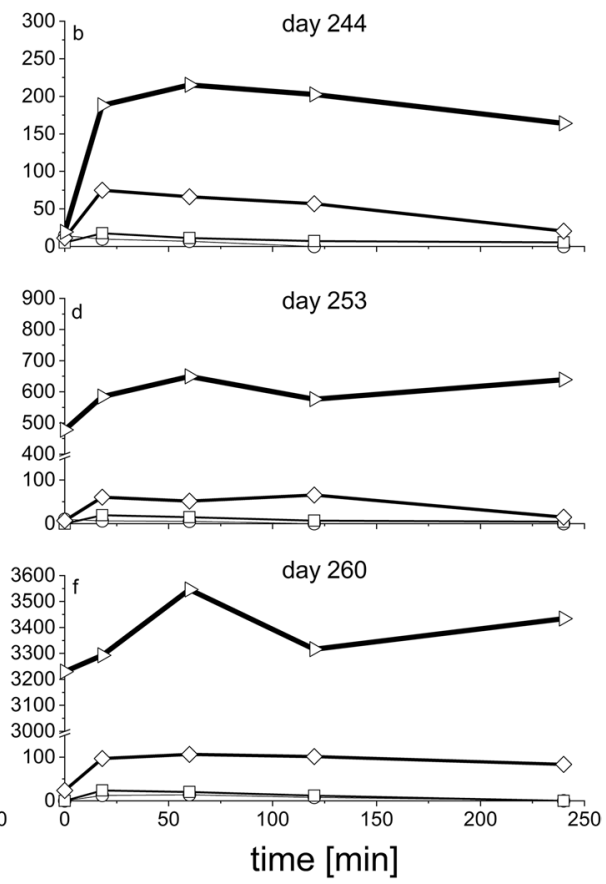
disturbance within the experimental time but the accumulation of acetate can be an early indicator for process overloading and incomplete degradation. For all CSTR the acetic acid concentration did not exceed $300 \mathrm{mg} \mathrm{L}^{-1}$ at any time.

The propionate concentration in CSTR 1 and CSTR2 was always below the acetic acid concentration. This was also observed in CSTR3 with $3.0 \mathrm{~kg}_{\mathrm{vS}} \mathrm{m}^{-3} \mathrm{~d}^{-1}$ although an increasing trend was visible. The highest rise in acid concentrations occurred in CSTR4 where $649.3 \mathrm{mg} \mathrm{L}^{-1}$ propionate was measured on day 253 , reaching maximum values of $3547.0 \mathrm{mg} \mathrm{L}^{-1}$ on day 260.

The concentration of butyrate was also monitored throughout the experiment in all reactors but was only detected twice with $11.89 \mathrm{mg} \mathrm{L}^{-1}$ in CSTR1, day 260, and $24.67 \mathrm{mg} \mathrm{L}^{-1}$ in CSTR4, day 260 (data not shown).

The VFA threshold for indicating a stable AD is not uniformly described in literature. Mayer et al. [32] suggested a total VFA concentration of below $400 \mathrm{mg} \mathrm{L}^{-1}$ for stable biogas processes, whereas Wang et al. [33] focused on propionic acid and set the threshold for stable fermentation to below $900 \mathrm{mg} \mathrm{L}^{-1}$. Still, these values were strongly exceeded in CSTR4 with propionate concentrations above $3500 \mathrm{mg} \mathrm{L}^{-1}$ on day 260.

This massive accumulation of propionic acid shows the complexity of anaerobic digestion and the compelling synergy between acetogenic bacteria and methane-producing archaea. The degradation of propionic acid into educts for methane formation (acetate, formate, or hydrogen) is characterized by an unfavorable thermodynamic balance. Thus, this reaction is only possible when the cleavage products are directly used further by acid-degrading methanogens and require a close syntrophic relationship between both groups of microorganisms [31, 34-36]. The presence of acetateproducing bacteria (using $\mathrm{H}_{2}$ and $\mathrm{CO}_{2}$ ) also leads to favorable thermodynamics as $\mathrm{H}_{2}$ partial pressure is kept low [37].

Due to the highly interconnected degradation pathways, the ratio between acetic and propionic acid is commonly used as process stability parameter. A ratio of propionic to acetic acid $>1$ is an indicator of process disturbance especially when the propionic acid concentration is above
$1000 \mathrm{mg} \mathrm{L}^{-1}$ [38]. At the end of the experiment (day 260), the propionic to acetic acid ratio in CSTR4 was 24.5 , which indicated a severe inhibition of the fermentation process.

$\mathrm{Lv}$ et al. [13] were able to show that the single intermittent addition of the same amount of feedstock led to higher concentrations of VFA than providing the same amount of feedstocks in several additions. Partitioning the amount of feedstocks can prevent VFA accumulation. The different kinetic performances of the $\mathrm{AD}$ with methanogenesis being the rate-limiting step are especially important in the case of feedstocks rich in fast degradable carbohydrates. Even though intermittent feedstock supply was shown to increase specific biogas and methane yields [11, 12], it may lead to severe process imbalances, when the proportion of fastdegradable carbohydrates exceeds the limits of acid degradation capacity within the reactor.

\subsection{Exponential relationship between volatile fatty acid concentration and gas yield}

The specific biogas (sBY) and methane yields (sMY) are the decisive quality characteristics for biogas plants. Next to the $\mathrm{pH}$, temperature, and the feedstock composition, the gas yield is mainly influenced by the processing of intermediates and thus the stability of the degradation process $[5,39]$. The specific gas yields were calculated for phase 3 of the experiment from the amount of gas per 12-h-observation period (n) and the respective OLR (Table 3). The sBY for CSTR $1\left(635 \pm 14.7 \mathrm{~L}_{\mathrm{N}} \mathrm{kg}_{\mathrm{VS}}{ }^{-1}\right)$, CSTR2 $(634 \pm 6.2$ $\left.\mathrm{L}_{\mathrm{N}} \mathrm{kg}_{\mathrm{VS}}{ }^{-1}\right)$, and CSTR3 $\left(601 \pm 6.3 \mathrm{~L}_{\mathrm{N}} \mathrm{kg}_{\mathrm{VS}}{ }^{-1}\right)$ did not significantly differ although different OLR rates with different ratios of easily degradable $\mathrm{S}$ were provided. However, the sBY for CSTR4 $\left(537 \pm 8.9 \mathrm{~L}_{\mathrm{N}} \mathrm{kg}_{\mathrm{VS}}{ }^{-1}\right)$ was significantly lower by $16 \%, 15 \%$, and $11 \%$, respectively, compared to the reactors CSTR1-CSTR3.

The same effect was observed for sMY. The specific methane yields for CSTR1 $\left(376 \pm 8.8 \mathrm{~L}_{\mathrm{N}} \mathrm{kg}_{\mathrm{Vs}}{ }^{-1}\right)$, CSTR2 $\left(362 \pm 5.0 \mathrm{~L}_{\mathrm{N}} \mathrm{kg}_{\mathrm{Vs}}{ }^{-1}\right)$, and CSTR3 $\left(360 \pm 3.5 \mathrm{~L}_{\mathrm{N}} \mathrm{kg}_{\mathrm{VS}}{ }^{-1}\right)$ did not show significant differences. This was also observed for the methane content in produced biogas in
Table 3 Mean specific biogas and methane yield for the four CSTR at different OLR and HRT

\begin{tabular}{|c|c|c|c|c|c|c|}
\hline \multirow[t]{2}{*}{ Reactor } & \multirow{2}{*}{$\begin{array}{l}\text { OLR } \\
{\left[\mathrm{kg}_{\mathrm{VS}} \mathrm{m}^{-3} \mathrm{day}^{-1}\right]}\end{array}$} & \multirow{2}{*}{$\begin{array}{l}\text { HRT } \\
\text { [d] }\end{array}$} & \multicolumn{2}{|c|}{ sBY } & \multicolumn{2}{|c|}{ sMY } \\
\hline & & & $\mathrm{n}$ & {$\left[\mathrm{L}_{\mathrm{N}} \mathrm{kg}_{\mathrm{VS}}{ }^{-1}\right]$} & $\mathrm{n}$ & {$\left[\mathrm{L}_{\mathrm{N}} \mathrm{kg}_{\mathrm{VS}}{ }^{-1}\right]$} \\
\hline CSTR1 & 2.0 & 85.4 & 41 & $635^{\mathrm{a}}(14.7)$ & 41 & $376^{\mathrm{a}}(8.8)$ \\
\hline CSTR2 & 2.5 & 61.2 & 51 & $634^{\mathrm{a}}(6.2)$ & 51 & $362^{\mathrm{a}}(5.0)$ \\
\hline CSTR3 & 3.0 & 47.7 & 52 & $601^{\mathrm{a}}(6.3)$ & 52 & $360^{\mathrm{a}}(3.5)$ \\
\hline CSTR4 & 3.5 & 39.1 & 52 & $537^{\mathrm{b}}(8.9)$ & 52 & $286^{\mathrm{b}}(6.0)$ \\
\hline
\end{tabular}

Superscript letters show significant differences at $p<0.05$; numbers in parentheses show the standard error of the mean

CSTR continuously stirred tank reactor, $O L R$ organic loading rate, $H R T$ hydraulic retention time, $s B Y$ mean specific biogas yield, $s M Y$ mean specific methane yield, $n$ observation periods of $12 \mathrm{~h}$ 
CSTR1-CSTR3. The concentration of methane varied between 58 and $62 \%$ with no significant differences. It must be considered that increasing the OLR while keeping the same reactor volume decreases the hydraulic retention time (HRT). With shorter HRT, the digestate can still contain undigested organic compounds and thus unused biogas and methane potential [40].

The sMY of $286 \pm 6.0 \mathrm{~L}_{\mathrm{N}} \mathrm{kg}_{\mathrm{vs}}{ }^{-1}$ measured in reactor CSTR4 was significantly lower than the specific methane yields in the other reactors. The methane content of produced biogas in CSTR4 dropped to $40 \%$ at the end of the experiment. Higher OLR of S during intermittent feeding did not automatically lead to higher specific gas yields. This effect is also reflected in the volumetric biogas and methane production rates (vBPR, vMPR) that were evaluated in $10 \mathrm{~min}$ intervals throughout the experiment. The increase in vBPR and vMPR is immediately visible after the intermittent $S$ load. The high-resolution measurement enabled explicit monitoring of production dynamics and even visualized the gas release during each mixing interval. With increasing VFA accumulation in reactor CSTR4 biogas and methane production were not only decreasing during the production peak but throughout the entire 12-h observation period. The effect of acidification was stronger on methane production than on the total gas production. Biogas and methane production rates in CSTR 1-3 were not affected during the experimental time. According graphs are given in Online Resource Figs. S1 (CSTR1), S2 (CSTR2), S3 (CSTR3), and S4 (CSTR4).

Eccleston and Bongards [41] also observed a negative impact of intermittent feedstock supply on biogas production. The evaluated stress index corresponded to each feeding event, while increased feeding amounts resulted in higher calculated stresses. However, no data about VFA load were acquired in their study.
The ample accumulation of VFA and the decreasing methane production in CSTR4 caused a kinetic uncoupling of the syntrophic relationship of acetogenic bacteria and methanogenic archaea with the thermodynamically most unfavourable degradation of propionic acid causing its accumulation [36, 42]. Bonk et al. [43] demonstrated that at process failure due to overload, the total VFA concentration increased up to fourfold at simultaneously occurring $\mathrm{pH}$ drop.

Boe et al. [44] suggested to closely monitor propionate concentrations and to use this parameter for controlling feedstock input to prevent reactor overloading. Acetate is less convincing as it is formed during various degradation steps and shows an unstable trend that disqualifies as early indicator [36]. The HRT for CSTR4 was 39.1 days that additionally can strain the microorganism agglomerations and causing VFA to accumulate. Archaea have a longer generation time than most bacteria. This can create an additional imbalance between the fermentation steps [45, 46]. Still, the HRT is longer than recommended to secure a stable process performance and to prevent a washout of methanogens that are slow-growing and need a minimum HRT of 10 days [37, 47].

Capson-Tojo et al. [48] also recommend propionate monitoring as a result of their experiments in batch reactors. The batch situation can be transferred to the requirements of flexible biogas production with feedstock management since intermittent overloading occurs for both operating modes. Controlling the supply of the feeding event only regarding methane or biogas yield in their experiments led to acid accumulation, especially of propionic acid, due to the slow-growing propionic acid degraders that could not develop fast enough for a new feeding batch. Recording acid concentrations was therefore concluded as an integral part of the monitoring routine to secure stable gas yields.
Fig. 5 Correlation between mean VFA concentration (given as means of each five measurements for an S feeding event) and specific biogas (a) and methane yield (b). CSTR continuously stirred tank reactor, VFA volatile fatty acids
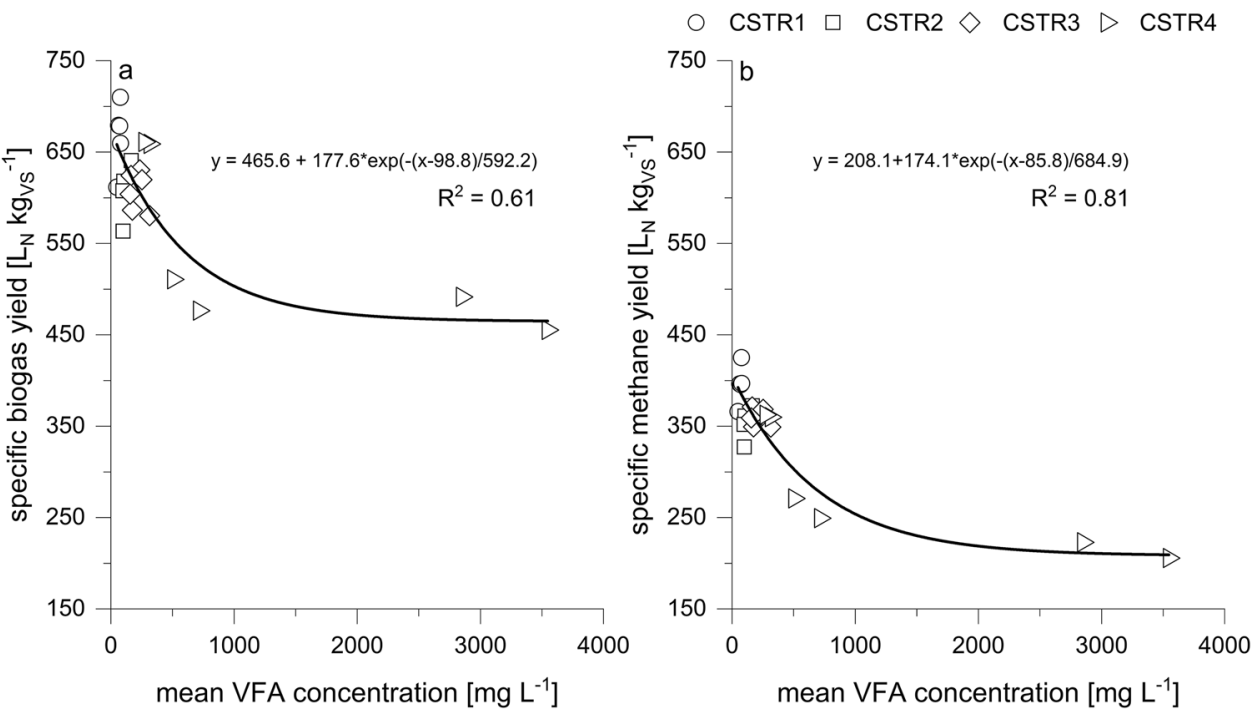
The results revealed a strong negative correlation of acid concentration, especially concerning propionic acid, to biogas and methane yields (Fig. 5).

The determination coefficient for $\operatorname{sMY}\left(R^{2}=0.81\right)$ is higher than for $\mathrm{SBY}\left(R^{2}=0.61\right)$, which indicates that VFA inhibit the last AD step, the methanogenesis [32]. Furthermore, an accumulation of VFA is associated with a drop in $\mathrm{pH}$ which releases $\mathrm{CO}_{2}$ from the bicarbonate buffer system. When more organic acids are produced during $\mathrm{AD}$ the equilibrium shifts from bicarbonate to carbonic acid that outright break down to water and $\mathrm{CO}_{2}$. The latter deteriorates the biogas quality by lowering the methane content in produced biogas even before the total biogas yield drops.

A decline in biogas and methane production is commonly known to occur due to overloading [49]. For intermittent biogas production through feedstock management, temporary overloads are part of the operating mode. Overloads that cannot be processed by the microorganisms lead to decreasing yields, accompanied by harsh economic consequences for biogas operators. AD that was inhibited by organic or hydraulic overloading needs, according to Regueiro et al. [50], at least 13 days of recovering time during which the OLR has to be reduced. Although biogas production in their experiments was returned to the levels before the disturbance, increased acidity was still observed. Biogas and methane production are not only decreased during overloading or acidification. Especially methane levels can remain low during the following recovering phase because the microbial community and especially archaea need time to adapt to the changing environment during and after overloading $[50,51]$ marking a process stability monitoring even more indispensable for every flexible biogas plant.

\section{Conclusion}

This study showed with high-resolution monitoring that VFA are produced within minutes after intermittent supply of fast degradable feedstocks like sugar beet silage. In stable reactors, the VFA increase is balanced by the buffer capacity and the metabolic activity, especially of the archaea. Specific biogas and methane yields are directly related to the amount of VFA, and the yields are declining rapidly at increasing VFA concentration. Therefore, caution must be taken especially when using fast degradable feedstocks. Thus, high-resolution process monitoring is indispensable for optimal biogas plant operation in order to meet challenging future requirements, especially regarding on-demand energy production.

Supplementary Information The online version contains supplementary material available at https://doi.org/10.1007/s13399-021-02043-2.
Author Contribution Conceptualization: Kerstin Maurus, Nicola Kremmeter, Marian Kazda; Data curation: Kerstin Maurus, Nicola Kremmeter; Formal analysis: Nicola Kremmeter; Investigation: Kerstin Maurus, Nicola Kremmeter, Sharif Ahmed; Resources: Kerstin Maurus, Nicola Kremmeter; Writing - original draft: Nicola Kremmeter; Writing - review and editing: Kerstin Maurus, Sharif Ahmed, Marian Kazda; Technical supervision: Sharif Ahmed; Supervision: Marian Kazda; Project administration: Marian Kazda.

Funding Open Access funding enabled and organized by Projekt DEAL. This work was financed by the German Federal Ministry of Food and Agriculture through its program "Renewable resources" (BMEL/FNR FKZ 22402115).

Data Availability Not applicable.

Code Availability Not applicable.

\section{Declarations}

Conflict of Interest The authors declare no competing interests.

Open Access This article is licensed under a Creative Commons Attribution 4.0 International License, which permits use, sharing, adaptation, distribution and reproduction in any medium or format, as long as you give appropriate credit to the original author(s) and the source, provide a link to the Creative Commons licence, and indicate if changes were made. The images or other third party material in this article are included in the article's Creative Commons licence, unless indicated otherwise in a credit line to the material. If material is not included in the article's Creative Commons licence and your intended use is not permitted by statutory regulation or exceeds the permitted use, you will need to obtain permission directly from the copyright holder. To view a copy of this licence, visit http://creativecommons.org/licenses/by/4.0/.

\section{References}

1. Hahn H, Krautkremer B, Hartmann K, Wachendorf M (2014) Review of concepts for a demand-driven biogas supply for flexible power generation. Renew Sustain Energy Rev 29:383-393. https://doi.org/10.1016/j.rser.2013.08.085

2. Ertem FC, Martínez-Blanco J, Finkbeiner M, Neubauer P, Junne $S$ (2016) Life cycle assessment of flexibly fed biogas processes for an improved demand-oriented biogas supply. Bioresour Technol 219:536-544. https://doi.org/10.1016/j.biortech.2016.07.123

3. Liu, Y., Huang, T., Li, X., Huang, J., Peng, D., Maurer, C., Kranert, M., 2020. Experiments and modeling for flexible biogas production by co-digestion of food wastes and sewage sludge. Energies 13 (818) https://doi.org/10.3390/en13040818.

4. Mauky E, Jacobi HF, Liebetrau J, Nelles M (2015) Flexible biogas production for demand-driven energy supply - Feeding strategies and types of substrate. Bioresour Technol 178:262-269. https:// doi.org/10.1016/j.biortech.2014.08.123

5. Maurus K, Ahmed S, Getz W, Kazda M (2018) Sugar beet silage as highly flexible feedstock for on demand biogas production. Sugar Ind. 143 (68). No 12:691-698

6. Mulat DG, Jacobi HF, Feilberg A, Adamsen APS, Richnow HH, Nikolausz M (2016) Changing feeding regimes to demonstrate flexible biogas production: Effects on process performance, microbial community structure, and methanogenesis pathways. Appl Environ Microbiol 82(2):438-449 
7. Ahmed S, Kazda M (2017) Characteristics of on-demand biogas production by using sugar beet silage. Anaerobe 46:114-121. https://doi.org/10.1016/j.anaerobe.2017.04.016

8. HN Gavala I Angelidaki BK Ahring 2003 Kinetics and modeling of anaerobic digestion process BK Ahring et al eds Biomethanation I. Advances in biochemical engineering/biotechnology Springer Berlin Heidelberg 815793

9. Ahmed, S., Einfalt, D., Kazda, M., 2016. Co-Digestion of sugar beet silage increases biogas yield from fibrous substrates. BioMed. Res. Int. 11 Article ID 2147513. https://doi.org/10.1155/2016/ 2147513

10. Mauky E, Weinrich S, Jacobi HF, Nägele HJ, Liebetrau J, Nelles M (2017) Demand-driven biogas production by flexible feeding in full-scale - Process stability and flexibility potentials. Anaerobe 46:86-95. https://doi.org/10.1016/j.anaerobe.2017.03.010

11. Terboven C, Ramm P, Herrmann C (2017) Demand-driven biogas production from sugar beet silage in a novel fixed bed disc reactor under mesophilic and thermophilic conditions. Bioresour Technol 241:582-592. https://doi.org/10.1016/j.biortech.2017.05.150

12. Maurus K, Ahmed S, Kazda M (2020) Beneficial effects of intermittent feedstock management on biogas and methane production. Bioresour Technol 304:123004. https://doi.org/10.1016/j.biortech. 2020.123004

13. Lv Z, Leite AF, Harms H, Richnow HH, Liebetrau J, Nikolausz $M$ (2014) Influences of the substrate feeding regime on methanogenic activity in biogas reactors approached by molecular and stable isotope methods. Anaerobe 29:91-99. https://doi.org/10. 1016/j.anaerobe.2013.11.005

14. Saracevic E, Frühauf S, Miltner A, Karnpakdee K, Munk B, Lebuhn M, Wlcek B, Leber J, Lizsasoain J, Friedl A, Gronauer A, Bauer A (2019) Utilization of food and agricultural residues for a flexible biogas production: Process stability and effects on needed biogas storage capacities. Energies 12(14):2678. https://doi.org/ $10.3390 /$ en 12142678

15. Laperrière W, Barry B, Torrijos M, Pechiné B, Bernet N, Steyer JP (2017) Optimal conditions for flexible methane production in a demand-based operation of biogas plants. Bioresour Technol 245:698-705. https://doi.org/10.1016/j.biortech.2017.09.013

16. Wagner AO, Reitschuler C, Illmer P (2014) Effect of different acetate: propionate ratios on the methanogenic community during thermophilic anaerobic digestion in batch experiments. Biochem Eng J 90:154-161. https://doi.org/10.1016/j.bej.2014.05.014

17. Ahring BK, Sandberg M, Angelidaki I (1995) Volatile fatty acids as indicators of process imbalance in anaerobic digestors. Appl Microbiol and Biotechnol 43:559-565

18. Hill DT (1982) A comprehensive dynamic model for animal waste methanogenesis. Transaction of the ASAE 25:1374-1380

19. Mathai PP, Nicholes MS, Venkiteshwaran K, Brown CM, Morris RL, Zitomer DH, Maki JS (2019) Dynamic shifts within volatile fatty acid-degrading microbial communities indicate process imbalance in anaerobic digesters. Appl Microbiol Biotechnol 104:4563-4575. https://doi.org/10.1007/s00253-020-10552-9

20. Wilches C, Vaske M, Hartmann K, Nelles M (2019) Representative sampling implementation in online VFA/TIC monitoring for anaerobic digestion. Energies 12:1179. https://doi.org/10.3390/ en12061179

21. Lindmark J, Thorin E, Bel Fdhila R, Dahlquist E (2014) Effects of mixing on the result of anaerobic digestion: Review. Renew Sustain Energy Rev 40:1030-1047. https://doi.org/10.1016/j.rser. 2014.07.182

22. Schnürer A, Bohn I, Moestedt J (2016) Protocol for start-up and operation of CSTR biogas processes. In: McGenity TJ, Timmis KN, Nogales B (eds) Hydrocarbon and Lipid Microbiology Protocols. Springer Verlag, Berlin Heidelberg, pp 171-200
23. Weißbach C, Strubelt C (2008) Correcting the dry matter content of sugar beet silages as a substrate for biogas production. Landtechnik 63(6):354-355

24. Voß, E., Weichgrebe, D., Rosenwinkel, K., 2009. FOS/TACdeduction, Methods, Application and Significance. Int. Confer. Biogas Sci., 2-4.

25. Drosg, B., 2013. Process monitoring in biogas plants. IEA Bioenergy, Task 37 Brochure.

26. Murto M, Björnsson L, Mattiasson B (2004) Impact of food industrial waste on anaerobic co-digestion of sewage sludge and pig manure. J Environ Manag 70(2):101-107. https://doi.org/10. 1016/j.jenvman.2003.11.001

27. Ye J, Li D, Sun Y, Wang G, Yuan Z, Zhen F, Wang Y (2013) Improved biogas production from rice straw by co-digestion with kitchen waste and pig manure. Waste Manage 33(12):2653-2658. https://doi.org/10.1016/j.wasman.2013.05.014

28. Amon T, Amon B, Kryvoruchko V, Zollitsch W, Mayer K, Gruber L (2007) Biogas production from maize and dairy cattle manure - Influence of biomass composition on the methane yield. Agric Ecosyst Environ 118:173-182. https://doi.org/10.1016/j.agee. 2006.05.007

29. Demirel B, Ergun S, Neumann L, Scherer P (2009) Performance and behaviour of the microbial community of an anerobic biogas digester using sugar beet silage as mono-substrate. Biosyst Eng 102(4):444-452. https://doi.org/10.1016/j.biosystemseng.2009. 01.008

30. Herrmann C, Idler C, Heiermann M (2016) Biogas crops grown in energy crop rotations: Linking chemical composition and methane production characteristics. Bioresour Technol 206:23-35. https:// doi.org/10.1016/j.biortech.2016.01.058

31. Klang J, Szewzyk U, Bock D, Theuerl S (2020) Effect of a profound feedstock change on the structure and performance of biogas microbiomes. Microorganisms 8:169. https://doi.org/10. 3390/microorganisms8020169

32. Mayer, F., Adam, C., Noo, A., Guignard, C., Hoffmann, L., Delfosse, P., 2010. Monitoring volatile fatty acid production during mesophilic anaerobic digestion exposed to increasing feeding rates. In: Proceedings of the $3^{\text {rd }}$ international symposium on energy from biomass and waste, Venice, Italy.

33. Wang Y, Zhang Y, Wang J, Meng L (2009) Effects of volatile fatty acid concentrations on methane yield and methanogenic bacteria. Biomass Bioenergy 16(6):407-416. https://doi.org/10.1016/j. biombioe.2009.01.007

34. Schink B (1997) Energetics of syntrophic cooperation in methanogenic degradation. Microbiol Mol Biol Rev 61(2):262-280

35. Gerardi MH (2003) The microbiology of anaerobic digesters. Wiley-Interscience. A John Wiley \& Sons, Inc., Publication, New Jersey

36. Li D, Chen L, Liu X, Mei Z, Ren H, Cao Q, Yan Z (2017) Instability mechanisms and early warning indicators for mesophilic anaerobic digestion of vegetable waste. Bioresour Technol 245:90-97. https://doi.org/10.1016/j.biortech.2017.07.098

37. Amani T, Nosrati M, Sreekrishnan TR (2010) Anaerobic digestion from the viewpoint of microbiological, chemical, and operational aspects - a review. Environ Rev 18:255-278. https://doi.org/10. 1139/A10-011

38. Weiland P (2010) Biogas production: current state and perspectives. Appl Microbiol Biotechnol 85:849-860

39. Panigrahi S, Dubey BK (2019) A critical review on operating parameters and strategies to improve the biogas yield from anaerobic digestion of organic fraction of municipal solid waste. Renew Energy 143:779-797. https://doi.org/10.1016/j.renene.2019.05. 040

40. Menardo S, Gioelli F, Balsari P (2011) The methane yield of digestate: Effect of organic loading rate, hydraulic retention time, 
and plant feeding. Bioresour Technol 102:2348-2351. https://doi. org/10.1016/j.biortech.2010.10.094

41. Eccleston R, Bongrads M (2020) Determining conditions of intermittently fed digesters from biogas production rate data. Chem Eng Technol 43(1):19-28. https://doi.org/10.1002/ceat.201900354

42. Dolfing J (2014) Thermodynamic constraints on syntrophic acetate oxidation. Appl Environ Microbiol 80:1539-1541. https://doi. org/10.1128/AEM.03312-13

43. Bonk F, Popp D, Weinrich S, Sträuber H, Kleinsteuber S, Harms $\mathrm{H}$, Centler F (2018) Intermittent fasting for microbes: how discontinuous feeding increases functional stability in anaerobic digestion. Biotechnol Biofuels 11(274):1-15

44. Boe K, Steyer J-P, Angelidaki I (2008) Monitoring and control of the biogas process based on propionate concentration using online VFA measurement. Water Sci Technol 57(5):661-666. https://doi. org/10.2166/wst.2008.046

45. Mi-Sun, K., Jeahwan, C., Dong-Hoon, K., 2013. Biohydrogen: Chapter 11 - Fermentative biohydrogen production from solid wastes. Elsevier Inc. Chapters, 259-283. https://doi.org/10.1016/ B978-0-444-59555-3.00011-8

46. Bernat K, Zielinska M, Gydzik-Kwiatkowska A, WojnowskaBaryla I (2015) Biogas production from different size fractions separated from solid waste and the accompanying changes in the community structure of methanogenic archaea. Biochem Eng J 100:30-40. https://doi.org/10.1016/j.bej.2015.04.011

47. Ju F, Lau F, Zhang T (2017) Linking microbial community, environmental variables, and methanogenesis in anaerobic biogas digesters of chemically enhanced primary treatment sludge. Environ Sci Technol 51:3982-3992. https://doi.org/10.1021/acs.est. 6b06344

48. Capson-Tojo G, Ruiz D, Rouez M, Crest M, Steyer J-P, Bernet N, Delgenès J-P, Escudiè R (2017) Accumulation of propionic acid during consecutive batch anaerobic digestion of commercial food waste. Bioresour Technol 245:724-733. https://doi.org/10.1016/j. biortech.2017.08.149

49. Theuerl S, Klang J, Prochnow A (2019) Process Disturbances in agricultural biogas production - Causes, mechanisms and effects on the biogas microbiome: a review. Energies 12(365):1-20. https://doi.org/10.3390/en12030365

50. Regueiro L, Lema JM, Carballa M (2015) Key microbial communities steering the functioning of anaerobic digesters during hydraulic and organic overloading shocks. Bioresour Technol 197:208-216. https://doi.org/10.1016/j.biortech.2015.08.076

51. Rétfalvi T, Tukacs-Hájos A, Albert L, Marosvölgyi B (2011) Laboratory scale examination of the effects of overloading on the anaerobic digestion by glycerol. Bioresour Technol 102:5270 5275. https://doi.org/10.1016/j.biortech.2011.02.020

Publisher's Note Springer Nature remains neutral with regard to jurisdictional claims in published maps and institutional affiliations. 